\title{
Central hyperexcitability in chronic musculoskeletal pain: A conceptual breakthrough with multiple clinical implications
}

\author{
Jan Lidbeck MD PhD
}

\begin{abstract}
J Lidbeck. Central hyperexcitability in chronic musculoskeletal pain: A conceptual breakthrough with multiple clinical implications. Pain Res Manage 2002;7(2):81-92.
\end{abstract}

Recent investigations of dysfunctional pain processing in the central nervous system have contributed much knowledge about the development of chronic musculoskeletal pain. Many common chronic musculoskeletal pain syndromes - including regional myofascial pain syndromes, whiplash pain syndromes, refractory work-related neck-shoulder pain, certain types of chronic low back pain, fibromyalgia and others - may essentially be explained by abnormalities in central pain modulation.

The growing awareness of dysfunctional central pain modulation may be a conceptual breakthrough leading to a better understanding of common chronic pain disorders. A new paradigm will have multiple clinical implications, including re-evaluation of clinical practice routines and rehabilitation methods, and will focus on controversial issues of medicolegal concern. The concept of dysfunctional central pain processing will also necessitate a mechanism-based classification of pain for the selection of indi- vidual treatment and rehabilitation programs for subgroups of patients with chronic musculoskeletal pain due to different pathophysiological mechanisms.

Key Words: Central sensitization; Chronic musculoskeletal pain; Mechanism-based pain classification; Pain modulation

Hyperexcitabilité centrale et douleur musculo-squelettique chronique : percée conceptuelle ayant de nombreuses répercussions cliniques

RÉSUMÉ : Les nouvelles recherches sur le processus dysfonctionnel de la douleur dans le système nerveux central ont permis d'en apprendre beaucoup sur l'apparition de la douleur musculo-squelettique chronique. De nombreux syndromes de douleur musculo-squelettique chronique, par exemple les douleurs myofasciales régionales, l'entorse cervicale, les

voir page suivante 
douleurs rebelles au cou et aux épaules d'origine professionnelle, certains types de lombalgie chronique, la fibromyalgie, etc., peuvent s'expliquer essentiellement par des anomalies de la modulation centrale de la douleur.

La sensibilité accrue à l'existence de la modulation dysfonctionnelle centrale de la douleur peut s'avérer une percée conceptuelle permettant de mieux comprendre les troubles courants de douleur chronique. Il s'agit là d'un nouveau paradigme qui aura de nombreuses répercussions cliniques; il obligera la collectivité médicale à revoir ses pratiques cliniques et ses méthodes de réadaptation et à se pencher sur des questions controversées d'ordre médico-légal. Ce concept de processus dysfonctionnel de la douleur d'origine centrale nécessitera également l'élaboration d'une classification de la douleur, fondée sur les mécanismes en cause pour permettre un choix approprié de programmes de traitement et de réadaptation dans des sous-groupes de patients souffrant de douleur musculo-squelettique chronique attribuable à différents mécanismes physiopathologiques.
$\mathrm{D}$ uring the past decade, new insight has been gained into the complex mechanisms of pain. Recent reviews of the modern concepts of the physiology of pain $(1,2)$, including the modulation of pain by peripheral and central mechanisms in the nervous system (3), have increased our understanding. Much interest has focused on dysfunctional central pain modulation and its importance for the development of chronic pain - in particular, long-standing neurogenic pain $(4,5)$. For example, dysfunctional central pain processing in postherpetic neuralgia and post-traumatic neuropathy has been described in detail (6-8). Studies of musculoskeletal pain have provided only hypothetical or theoretical models of central dysmodulation $(9,10)$. In recent years, however, a growing body of evidence from experimental and clinical investigations has more convincingly shown chronic musculoskeletal pain to be associated with central dysmodulation (11). The development of long-standing musculoskeletal pain due to dysfunctional central processing may be a conceptual breakthrough. A new paradigm for a better understanding of chronic musculoskeletal pain has many practical and clinical implications. One of the most important implications is the need for a new classification of pain based on pathophysiological mechanisms rather than on etiology or the pain region involved.

Only a few reviews on dysfunctional central pain modulation in chronic musculoskeletal pain have been published $(12,13)$. The aim of the present paper was to outline the modern research into the central pathogenesis of persistent regional and widespread musculoskeletal pain. It also focuses on certain clinical consequences.

\section{DYSFUNCTIONAL CENTRAL PAIN MODULATION}

Results from basic and clinical research have established that post-traumatic or inflammatory tissue damage may lead to peripheral nociceptive hyperexcitability, ie, peripheral sensitization (primary hyperalgesia). In addition, central sensitization may develop in the dorsal horn neurons and in other parts of the central nervous system following repeated and/or continuing peripheral noxious input (temporal summation). From a clinical perspective, a long-standing and refractory pain disorder may result (secondary hyperalgesia). Dysfunction of the descending nociceptive inhibition (dysfunctional inhibition) is another central mechanism involved in some chronic pain disorders. Thus, in dysfunctional central pain modulation, central sensitization and/or dysfunctional inhibition are the two principal mechanisms.

Only a few of the complex central mechanisms are outlined in the present paper. Details of abnormal central pain processing in persistent muscle pain have been described by others (14). It has been proposed that disorders characterized by dysfunctional central pain modulation be given the designation 'disorders of dysfunctional pain' (15), which will be used in the present review. The terms associated with dysfunctional pain are defined in Appendix 1.

\section{Central sensitization}

Experimental animal studies have shown that repetitive noxious input due to tissue damage or inflammation leads to a progressive increase in the magnitude of $\mathrm{C}$-fibreevoked responses of the dorsal horn neurons. This phenomenon is usually referred to as 'windup' and may lead to a 20 -fold increase in neuronal sensitivity $(5,8)$. Although it is reversible, windup is thought to initiate persistent sensitization of the dorsal horn neurons (16). Thus, windup and central sensitization are not quite equivalent. However, they are interrelated in that windup leads to expansion of the receptive fields and enhanced responses to C-fibre stimulation, which are some of the characteristics of central sensitization (17). Sensitization of the dorsal horn neurons is associated with the activation (depolarization) of $\mathrm{N}$-methyl-D-aspartate (NMDA) receptors (18).

Central sensitization may be a physiological response that normally reverses when the noxious input is eliminated. Kosek and Ordeberg (19) found widespread sensory abnormalities in patients with painful osteoarthritis of the hip, indicating central sensitization. After surgery, the sensory abnormalities reversed, suggesting that they had been maintained by nociceptive inflow. The reason why central sensitization appears to be irreversible in certain chronic pain disorders, such as fibromyalgia, is unknown. Peripheral nociceptive factors cannot be excluded as playing a significant role in some patients.

Thus, while windup does not persist, the central sensitization may be long lasting, as was exemplified in one animal study of central sensitization by the finding that repetitive noxious stimulation of an inflamed extremity resulted in progressive and persistent tactile hypersensitivity (20). Continuing peripheral nociception led to a decreasing pain threshold that remained low even after the noxious input had been discontinued. Substantial documentation from clinical research supports a similar development of refractory chronic pain in humans (5). From a clinical perspec- 


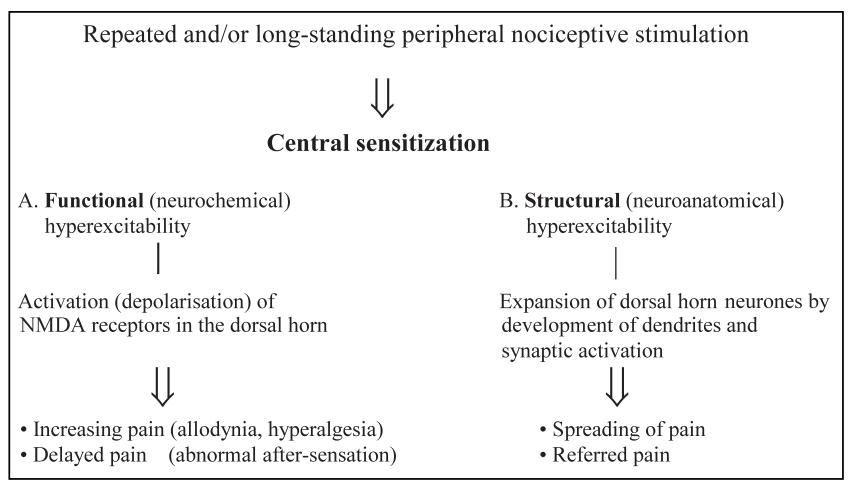

Figure 1) Simplified model of central sensitization and its consequences associated with some clinical characteristics of chronic pain. NMDA N-methyl-D-aspartate

tive, central sensitization is associated with the finding of allodynia, hyperalgesia and delayed pain (Appendix 1), all of which are characteristics of chronic pain.

Central sensitization involves functional (neurochemical) as well as structural (neuroanatomical) abnormalities of the dorsal horn neurons (Figure 1). One functional abnormality is the activation of NMDA receptors, which are assumed to be a cause of allodynia and hyperalgesia. Structural changes include the development of dendrites and activation of latent synapses, which in humans may cause the spreading and referral of pain.

The development of neural structural abnormalities in patients with chronic pain is the result of the plasticity of the central nervous system (21). Modern research in the field of neuropsychology has presented evidence of changes in cortical structures after long-standing peripheral nociception (22). In patients with chronic low back pain (CLBP), for example, the somatosensory cortical representation of the lower back has been shown to change and reorganize (23).

\section{Dysfunctional inhibition}

In the normally functioning central nervous system, several mechanisms are involved in the inhibition of nociceptive input. A segmental inhibition by the activation of endorphin-dependent neurons in the dorsal horn has been recognised for a long time. Additionally, recent investigations have focused on the descending inhibition (diffuse noxious inhibitory control) from midbrain and brain stem neurons involving neurotransmitters such as serotonin and noradrenaline. Defective descending pain inhibition (dysfunctional inhibition) with deficiencies in serotonin metabolism has been proposed to be one mechanism for the development of fibromyalgia (24-26). Dysfunctional inhibition likely also has a role in other chronic pain disorders and acts in combination with central sensitization.

\section{Symptoms}

Evidence from research $(3-5,9,14,18)$ strongly supports the association of certain clinical features (Table 1) with dysfunctional pain. In the absence of objective findings, such

\section{TABLE 1}

Medical history, pain-drawing characteristics and certain clinical findings indicative of dysfunctional central pain modulation in chronic musculoskeletal pain disorders

\section{Medical history \\ Long duration of pain \\ Spreading of pain, sometimes development of widespread pain \\ Easily provoked pain - by a mild to moderate physical workload (household work, physical therapy), even after long periods of absence of demanding, physical work tasks \\ Muscular weakness in peripheral extremities ("plates slip out of hand", hand-work not possible)}

Reduced power of endurance - discontinuation of occupational testing or dropping out of rehabilitation programs that are too intensive

Absence of treatment effects - acupuncture is generally ineffective or increases pain, and common (peripherally active) analgesics are usually not effective

Absence of data supporting the possibility of undiagnosed neuropathic pain of peripheral origin

Pain-drawing characteristics

Frequent widespread regional or generalized pain

Mixed quality of pain - both neuropathic (burning, tingling, pricking) and nociceptive (dull, deep, pulsating, diffuse) pain descriptors

Neuroanatomically diffuse symptoms in peripheral extremities including referred pain and dysesthesia (numbness, pricking sensations, hyperesthesia)

Frequent peripheral symptoms of autonomous dysfunction (sensations of cold and/or heat, swelling)

Clinical findings

Sensory abnormalities; dysesthesia (as above), generally diffuse and transient

Regional or generalized allodynia and/or hyperalgesia often with 'jump-sign'

Hyperalgesic muscle trigger points characterized by peripheral referral of pain and/or dysesthesia

Reproducible symptoms, ie, the patient recognizes the symptoms evoked (patient recognition)

Increasing pain, peripheral dysesthesia and/or sense of heaviness minutes or hours after the physical examination, which may persist for hours or days (delayed pain)

Absence of specific findings indicating neuropathic pain of peripheral origin

symptoms may be difficult to comprehend for the examining physician. The presence of distally referred pain $(18,27)$, and diffuse and inconsistent dysesthesia that characteristically do not follow segmental or neuroanatomical patterns of distribution (Figure 2), is confusing $(28,29)$. Often the patient's description of pain and the observed pain reactions are interpreted as 'nonorganic signs' (30) or as features of 'psychogenic' pain. Easily evoked shoulder pain referring to the arm and the hand is frequently found 


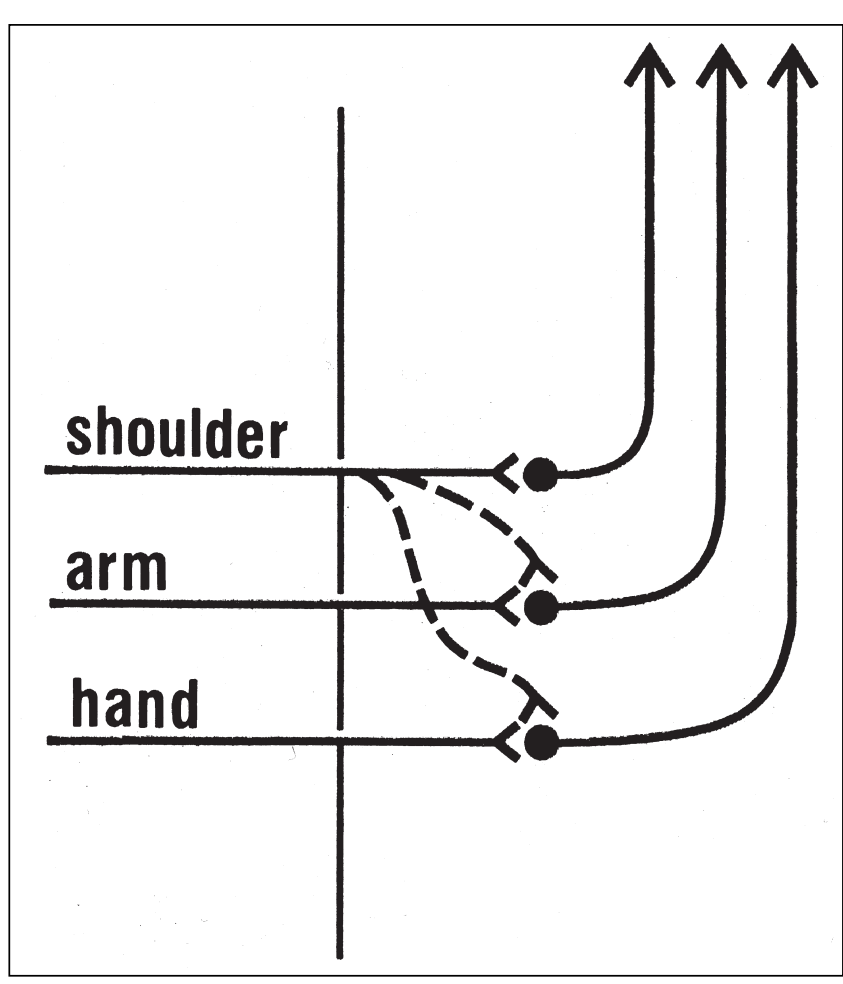

Figure 2) A model of a mechanism for pain referral in chronic muscle pain due to central hyperexcitability. Dorsal horn neurons normally receiving peripheral nociceptive input from the arm and the hand engage by the activation of latent synaptic connections from noxious input from the shoulder muscles. Shoulder pain refers distally to the arm and hand, characteristically without segmental or otherwise neuroanatomical distribution

in chronic neck-shoulder disorders such as work-related cervicobrachial pain and whiplash syndromes. Referred pain is a feature of intense pain and may be associated with the activation of synapses connecting to adjacent dorsal horn neurons (Figure 2). Usually, pain can be provoked long after what is considered to be a normal healing time and even years after the initial trauma. Gentle palpation or mild muscular workload easily evokes pain that increases after minutes or hours (temporal summation) and sometimes does not subside until days later (prolonged after-sensation [31]). Such abnormal delayed pain (Table 1) may be a result of NMDA receptor activation.

\section{DYSFUNCTIONAL PAIN IN MUSCULOSKELETAL DISORDERS}

Not all patients with long-standing nociception present with dysfunctional pain symptoms. Following whiplash injury, only a small minority develop chronic pain, and those with fibromyalgia comprise only about $2 \%$ to $3 \%$ of the general population. Genetic predisposition, pain experienced in the neonatal period, the intensity and persistence of initial pain, and emotional factors may be important (32-34). However, long-standing and refractory musculoskeletal pain is very common, and people with this disorder make up the largest patient group in many pain management settings (35). There is considerable support for the assertion that many chronic musculoskeletal pain disorders are caused by dysfunctional pain modulation. Some categories are described below.

\section{Post-traumatic pain and whiplash}

Dysfunctional pain as a cause of persistent pain after injury has long been discussed in pain research (36). Seemingly insignificant tissue injury (mild injury) may result in disabling pain disorders such as post-traumatic headache syndrome (37) or whiplash-associated dysfunction syndrome (WAD). Intense pain during injury associated with emotional shock may promote the development of central sensitization in predisposed individuals. Thus, chronic refractory pain is also common in patients with post-traumatic stress disorders (PTSD) after traffic accidents, assault or torture $(38,39)$.

The mechanism underlying long-standing pain following whiplash trauma is not well understood (40); it is probably complex, involving both peripheral and central factors. In $5 \%$ to $10 \%$ of patients with whiplash trauma an easily evocable and chronic cervicobrachial pain syndrome develops (WAD), sometimes with functional deficits due to muscle shortening (41). The majority characteristically also present with regional allodynia and hyperalgesia, distally referring pain, distal dysesthesia (paresthesia, sensory abnormalities) and delayed pain. There is often a history of pain spreading to adjacent body regions.

The frequent absence of demonstrable major bone or nerve damage has focused research on the possibility of muscle or zygapophysial joint injury (42), with primary hyperalgesia and secondary development of central sensitization. Recent clinical research has even suggested that patients with whiplash have generalized central hyperexcitability. Intramuscular infusion of hypertonic saline into the leg of patients with WAD resulted in local hyperalgesia, abnormal spreading of pain and delayed pain (43). Other similar studies have added further support to the presence of generalized dysfunctional pain in WAD. Moog et al (44) reported that whiplash patients experienced hyperalgesia on vibration stimulation outside areas of pain. Curatolo et al (45) presented evidence of lowered pain thresholds after intramuscular electrical stimulation of the lower limb. Interestingly, the clinical symptoms of WAD and the findings on physical examination are identical to those seen in patients with chronic myofascial pain syndromes (MPS) (trigger point syndrome; see below) localized to the neckshoulder region. Consequently, MPS can be diagnosed in most patients with WAD $(40,46-48)$, and some patients even develop fibromyalgia $(49,50)$.

Central sensitization has been discussed in textbooks on whiplash injury as a possible explanation for chronic pain (51). Sheater-Reid and Cohen (52) presented a detailed description of dysfunctional pain in patients with chronic neck pain disorders, including WAD. A recent review by Munglani (53) of the neurobiological mechanisms underlying WAD focused on central sensitization. Foreman and 
Croft (51) suggested that early and effective analgesia after whiplash injury might prevent the development of dysfunctional pain.

\section{MPS}

Regional muscle pain, usually localized to the neck-shoulder region, is a frequent pain syndrome in Swedish women who are exposed to monotonous, repetitive work (35). In its chronic form, it is characterized by muscle shortening and stiffness, hyperalgesic trigger points with peripherally referring pain, dysesthesia and weakness. Delayed pain is also common. Regional muscle pain with these specific features has been designated MPS (54). Notably, MPS is identical to 'trigger point syndrome' as defined by the International Association for the Study of Pain (IASP) in its Classification of Chronic Pain (55).

The symptoms of MPS may be similar to those of neuropathic pain on first examination (28). MPS is commonly erroneously diagnosed as cervical rhizopathy, thoracic outlet syndrome, carpal tunnel syndrome or some other peripheral nerve entrapment syndrome $(28,35)$. However, information from the medical history, pain-drawing characteristics and clinical findings usually leads to a correct diagnosis (Table 1). Characteristically, and contrary to neuropathic pain due to rhizopathy (nerve root compression) or nerve entrapment, the distally radiating symptoms of MPS are diffuse and override neuroanatomical borders. Moreover, the peripheral sensory abnormalities are variable or transient, causing confusion (28).

The similarity between the features of long-standing muscle pain and neuropathic pain indicate that they have a common causal central mechanism. Experimental investigation has shown that primary muscle nociception, as nerve injury in peripheral neuropathic pain disorders, leads to functional dorsal horn abnormalities (56) associated with hyperalgesia and the spreading of pain that becomes persistent (57). Within a few hours of experimental myositis, dorsal horn neurons activate latent synapses and connect to adjacent cells, which may explain pain referral (Figure 2) and spreading (58). Muscle inflammation has also been demonstrated to cause central hyperexcitability through NMDA receptor activation (59). A review by Coderre et al (60) of the experimental evidence added further support to the concept that tissue damage, not only of peripheral nerves, may lead to central hyperexcitability that sometimes persists long after the normal healing time. Another major review of central hyperexcitability in muscle pain has been presented by Ursin et al (10).

Recent clinical investigations also support the notion that dysfunctional central pain modulation may explain many chronic musculoskeletal pain disorders. Sheater-Reid and Cohen $(52,61)$ presented evidence of a lowered pain threshold and allodynia in patients with chronic cervicobrachial pain syndromes, which indicates central hyperexcitability. Trigger points in chronic MPS have been suggested as regions of secondary hyperalgesia due to central sensitization $(12,62)$. Additionally, a Danish study of patients with MPS has shown that quantitatively altered nociception is a probable cause of central hyperexcitability (63). An increasing number of reports have added further evidence to the model of dysfunctional pain in regional muscular pain disorders in general $(9,11,12,27,64)$, in myofascial tension-type headache (65) and in temporomandibular pain disorders $(14,66,67)$. The finding of dysfunctional pain in temporomandibular disorders has been proposed to be a conceptual breakthrough to a better understanding of the underlying pain mechanism (14).

\section{Work-related pain syndromes}

The association of muscle pain syndromes in the neckshoulder region with repetitive, monotonous work is well established (68). In occupational medicine, such pain syndromes are designated 'occupational cervicobrachial disorders' (OCDs). The constellation of chronic symptoms of OCD is identical to that of MPS $(61,68)$. When peripheral nociception continues, and in vulnerable individuals, there is an increased risk of developing central hyperexcitability, causing chronic pain. Such a model is supported by the observation that OCD often persists long after the exposure to noxious work has been discontinued (compare with MPS above [60]) and sometimes even years after retirement. In such cases, there is no demonstrable remaining muscle tissue damage (9).

In the 1980s, an increasing number of workers' compensation claims were made in Australia for what was then termed 'repetitive strain injury' (RSI). RSI was generally a refractory cervicobrachial pain disorder characterized by the absence of objective findings of tissue injury. After legislative restrictions, the number of occupational injury claims declined dramatically. This decline was uncritically assumed to be a result of RSI being caused by social and psychogenic factors (9). The problem of RSI is currently being re-evaluated. The previously unexplained symptoms in refractory RSI have been proposed to be caused by central hyperexcitability $(9,61)$.

\section{CLBP}

Current pathophysiological concepts of CLBP include centrally dysfunctional pain mechanisms $(12,69)$. Results from a recent Swedish doctoral thesis on pharmacological pain analysis supported the view of CLBP as idiopathic, ie, inexplicable, in one-third of patients (70). The infusion of morphine had no effect on pain in patients with neuropathic or idiopathic CLBP. In idiopathic as well as neurogenic pain, morphine resistence may be due to the involvement of activated NMDA receptors, which do not respond to the administration of morphine (12). Thus, in some individuals with CLBP categorized as idiopathic, central hyperexcitability cannot be excluded as an underlying pain mechanism (71).

Assessment of pain thresholds by the use of a dolorimeter has revealed the presence of generalized allodynia in patients with CLBP, even to the extent that fibromyalgia could be diagnosed in some patients (72). Further, one 
recent study of CLBP using magnetic source imaging provided strong evidence of enhanced cortical reactivity, which has been suggested to be a consequence of painrelated dorsal horn hyperexcitability (23). The magnitude of the cortical response to tactile stimulation was positively related to the chronicity of pain. Moreover, Sidhall and Cousins (73) recently described central sensitization as well as dysfunctional inhibition in a focus article in Spine. Dysfunctional pain was presented as an important mechanism, adding to the knowledge of chronic back pain. The finding of the primary sensitization of lumbar nerve roots noxiously exposed to tissue leaking from injured disks and the development of secondary central hyperexcitability as a cause of CLBP and sciatica have also been described $(74,75)$.

\section{Fibromyalgia}

Previous investigations of fibromyalgia have concentrated on peripheral muscular factors (disturbed microcirculation, damage to endothelial cells and the presence of 'ragged red fibres') as the cause of pain in fibromyalgia. However, such peripheral changes are not specific for fibromyalgia. There is a widely held opinion among fibromyalgia research groups that peripheral muscular changes are not the cause of widespread pain in fibromyalgia. However, in a subgroup comprising about $30 \%$ to $40 \%$ of patients who develop fibromyalgia, there is a history of preceding regional pain, such as work-related neck-shoulder pain, whiplash pain or low back pain, and local muscle tension may be present. Thus, peripheral nociception may still contribute to persisting regional pain in some patients with fibromyalgia.

In recent years, however, clinical research on fibromyalgia has focused on central hyperexcitability $(26,76)$. The majority of patients do not have a history of a local pain disorder. Many develop chronic widespread pain for no obvious reason, whereas others are still given a diagnosis of fibromyalgia following infection or prolonged emotional distress. Further, fibromyalgia is characterized by widespread allodynia and hyperalgesia, usually involving both superficial tissues (skin, fat) and deeper structures (muscles, joints). These characteristics strongly indicate a generalized (central) dysfunction of pain modulation. There is also considerable evidence associating other symptoms of fibromyalgia, such as abnormal fatigability, exhaustion, cognitive deficiencies, irritable bowel syndrome, etc, with multiple neuroendocrine dysfunction (77), including abnormal central stress responses. Thus, many researchers consider chronic pain in fibromyalgia to be only one symptom of generalized dysfunctional processing in the central nervous system.

In the search for an explanation for allodynia and hyperalgesia in fibromyalgia, central dysfunctional inhibition primarily attracted much interest as the dominating mechanism $(24,25,78,79)$. The finding of decreased serotonin in cerebrospinal fluid supports this concept. However, in recent years, complementary investigations have focused on the development of central sensitization in fibromyalgia. Sörensen (70), for example, demonstrated that an infusion of the NMDA receptor antagonist ketamine reduced pain in the experimental treatment of patients with fibromyalgia. Similar results were reported by Graven-Nielsen et al (18) for a major subgroup of patients with fibromyalgia. The finding of a qualitatively altered nociception in patients with fibromyalgia supports the concept of central hyperexcitability (80). A recent Swedish doctoral thesis presented further evidence of central sensitization in fibromyalgia, although it did not exclude concomitant dysfunctional inhibition (81). Elevated levels of substance P found in cerebrospinal fluid may also contribute to central hyperexcitability in fibromyalgia $(82,83)$.

In summary, there is an increasing body of evidence that refractory and previously poorly understood chronic musculoskeletal pain disorders are caused to a large extent by dysmodulation of central pain processing. Current clinical research will add further support to this model (12). The novel focus on dysfunctional pain does not, however, exclude the possibility that peripheral factors play an important role. Interestingly, anesthetic blocks of the zygapophysial joints have been reported to reduce pain in patients with WAD (84). Thus, peripheral and central factors may interact, in that persistent peripheral stimulation may maintain central hyperexcitability to a lesser or greater extent $(18,19,85)$. Fibromyalgia and WAD may be examples of such an interaction.

\section{CLINICAL CONSEQUENCES}

The growing awareness of central pain mechanisms has several important consequences. Most importantly, the concept of dysfunctional pain may stress the need for a mechanism-based pain classification. Other consequences involve the patient-physician relationship, routines in clinical practice, rehabilitation and medicolegal issues. Some of these consequences are discussed below.

\section{Improvement of the patient-physician relationship} In clinical practice, long-standing and complex pain disorders are difficult to understand when pain is diffuse and when ordinary objective clinical findings are lacking (30). Patients become frustrated when they cannot be given an explanation for their suffering. Pain reactions ('jump signs' and delayed pain) and other features of chronic pain may be regarded as nonorganic signs or as evidence of psychological pain behaviour (86). The patient becomes a 'problem patient', and confrontation between doctor and patient is common, adding to the suffering of the patient and to the frustration of the helpless physician.

The concept of dysfunctional pain certainly facilitates a positive patient-physician relationship and a better understanding of patients' pain and suffering. The model also offers an explanation to the patient (53). Previously inexplicable sensitivity to touch, easily evocable pain and pain referral can be understood in terms of dysmodulation of pain in the central nervous system. The earlier, sometimes one-sided, concept of psychological or ill-defined psychosomatic pain becomes more integrated when a more compre- 
hensible neurosomatic dimension of pain is included. Offering a communicable neurophysiological explanation of pain to frustrated patients is of fundamental importance for constructive coping and successful rehabilitation (87).

\section{Revision of clinical routines}

The growing knowledge of dysfunctional pain can be expected to result in a re-evaluation of the many routines in medical care.

- Continuing the search for peripheral noxious stimuli may not be meaningful. Identification of clinical signs associated with dysfunctional pain (Table 1) will likely be more rewarding.

- Physical therapy that is too intensive may be harmful and is generally contraindicated. Central hyperexcitability increases pain, and patients may lose motivation, even for more appropriate rehabilitation programs.

- Surgical and invasive procedures should be avoided. Strict indications for surgery of assumed carpal tunnel syndrome and other suspected peripheral nerve entrapment disorders should be considered. Increasing awareness of dysfunctional pain is necessary in surgical specialties.

- Early preventive measures in occupational medicine are essential. Harmful work should be discontinued. For certain individuals, continuing noxious labour may lead to refractory dysfunctional pain, long term sick leave and permanent disability.

\section{Criticism of vocational rehabilitation programs}

Patients with chronic pain due to dysfunctional pain have often been referred to vocational rehabilitation programs inspired by the so-called work-hardening model, characterized by a stepwise increase in muscular workload in various types of physical training. In patients suffering from dysfunctional pain, such vocational programs may cause increasing central hyperexcitability. Dropping out of the program due to increasing pain and disability has sometimes been regarded as motivational failure and may have disastrous medicolegal and economic consequences for the patient.

Injured patients who have participated in work-hardening programs are still common as late referrals to specialized pain management settings. These individuals are often refractory to further treatment or more adequate rehabilitation. In the 1990s, official Scandinavian vocational rehabilitation guidelines recommended work-hardening programs. Through such guidelines, general practitioners in Sweden were informed that the absence of verifiable clinical findings indicated an "inappropriate augmentation of symptoms or inadequate pain behaviour" and that widespread pain was caused by psychological overreaction. Many patients referred to certain work-hardening vocational rehabilita- tion programs deteriorated, even to the extent that their rehabilitation had to be discontinued (88). Thus, in one study comprising 168 patients, no less than half of the patients dropped out of rehabilitation (89). Several Scandinavian studies have similarly reported poor results of the work-hardening model (90-92). In Sweden, financial support from the National Insurance Authority has been approved for work-hardening programs without previous consensus from pain medicine or rehabilitation specialists (93).

\section{Medicolegal re-evaluation}

The previously widely held opinion that chronic pain is caused mainly by primary psychological and/or psychosocial factors is not supported by strong scientific evidence. Due to the awareness of misleading selection bias and the use of inappropriate psychometric assessment instruments in the past, the dualistic concept of 'psychogenic' pain is being questioned $(94,95)$. The increasing knowledge of dysfunctional central pain processing necessitated critical re-evaluation. Significantly, Main and Waddell (96) warned against a continuing simplistic interpretation or misuse of the socalled Waddell nonorganic signs (30) in the clinical examination of patients with low back pain.

However, a controversial report of the IASP Task Force on Pain in the Workplace (97) recommended that nonspecific back pain not be considered a medical problem but rather a problem of 'activity intolerance'. Further, for patients in whom function was not restored and return to work was not achieved, it was suggested that disability be reconceptualized as unemployment, allowing the termination of sickness benefits. This proposal has been criticized (98-104) because the Task Force neglected to consider recent investigations of central hyperexcitability. The criticism underlined the "growing body of evidence establishing chronic musculoskeletal pain to have a neurophysiological basis" (101).

\section{Need for a mechanism-based pain classification}

Chronic pain disorders have traditionally been diagnosed clinically according to the involvement of body region (such as low back pain, cephalalgia and neck-shoulder myalgia), organ system (musculoskeletal, gastrointestinal) or etiology (post-traumatic, degenerative or inflammatory pain). However, dysfunctional pain, being an important mechanism for persistent pain, irrespective of region, system or etiology, calls for a complementary mechanismbased pain classification, which will be necessary in the pain clinic to understand pain better and to make treatment more efficient.

A first step toward a mechanism-based classification is to conduct a pain analysis (105). This is a routine procedure in many anesthesiological pain clinics in Scandinavia. In pain analysis, various types of pain are identified according to the pathophysiology of the pain-generating mechanism (105). Pain is then categorized principally into nociceptive, neurogenic, idiopathic and (genuine) psychological pain 
TABLE 2

\section{Classification of pain according to pain mechanisms (pain analysis)}

Traditional scheme

Nociceptive pain (tissue damage, trauma, inflammation, mechanical)

Neurogenic pain

Peripheral (rhizopathy, herpes zoster, trigeminal neuralgia)

Central (neurological disease such as stroke, multiple

sclerosis, syringomyelia)

Idiopathic pain (unknown pain mechanism such as fibromyalgia, myofascial pain syndrome, chronic whiplash pain syndrome)

\section{Psychological pain (psychiatric disease, major} psychopathological disorder)

\section{A model for a revised scheme: dysfunctional pain as a new category \\ Nociceptive pain \\ Neurodysfunctional pain \\ Peripheral (as above) \\ Central \\ - Specific neurological disease (as above) \\ - Chronic pain disorders with major involvement of dysfunctional central pain modulation (dysfunctional pain; including persistent neuropathic pain, fibromyalgia, myofascial pain syndrome, whiplash pain syndrome, etc)}

Idiopathic pain (pain mechanism in some disorders will still remain unknown)

Psychological pain

Dysfunctional central pain processing in chronic musculoskeletal pain will require a revision of the traditional scheme of pain categories

(70,105,106 [Table 2]). Many chronic pain disorders previously regarded as idiopathic, such as fibromyalgia and certain MPS, can be explained to a large extent by dysfunctional pain. Thus, these disorders should no longer be categorized as idiopathic but rather as "neurodysfunctional' due to the involvement of central pain dysmodulation (35). This change will require a modification of the traditional scheme of pain categories (Table 2).

Previously, and certainly in anesthesiological pain centres, pharmacological testing has been the tool for pain analysis (pharmacological pain analysis [70]). However, in pain rehabilitation clinics, the alternative will be to make a clinical pain analysis based on information obtained from history, pain questionnaires (including a pain drawing) and physical examination. This option may be equally efficient because characteristic clinical features can be used to identify dysfunctional pain disorders (Table 1). In the international pain research community, discussion has been initiated to prepare for new approaches to identifying pain mechanisms based on a similar clinical model for pain analysis $(107,108)$.

The clinical use of a mechanism-based classification of pain will have important implications for the selection of treatment and rehabilitation methods. For instance, patients with mainly nociceptive pain can be assumed to benefit from treatment with common analgesics or acupuncture. They may also respond beneficially to workhardening rehabilitation, contrary to individuals with dysfunctional pain. Patients with pain involving dysfunctional central processing should be identified early and referred to treatment programs including mild physical exercise. The focus should be on cognitive restructuring.

\section{Pharmacological options}

Neither peripheral nociceptive nor central endorphindependent mechanisms are thought to play a major role once dysfunctional pain is established. This may explain why, in the clinical experience, common analgesics, even opioids, generally have little effect in the treatment of dysfunctional pain $(12,109)$. In fact, the proposed 'analgesic ladder' (110) is not very useful as a treatment guide for dysfunctional pain.

Treatment with tricyclic antidepressants is an alternative for some patients. Tricyclics, and principally amitriptyline, have been documented to be effective in the treatment of chronic neuropathic pain (111) and to some extent in the treatment of fibromyalgia (112). It has been suggested that tricyclics facilitate descending central pain inhibition pathways by blocking the reuptake of serotonin and noradrenaline. The selective serotonin reuptake inhibitors have not been sufficiently tested for the treatment of dysfunctional pain. However, the increasing knowledge of central pain mechanisms may lead to future options for more efficient drug treatment. The possibility of blocking NMDA receptors by the administration of NMDA antagonists has attracted much interest. Interestingly, tricyclics may have an antagonistic effect on NMDA receptors (113). Dextromethorphan is another NMDA receptor antagonist that may inhibit windup (114) and decrease centrally mediated hyperalgesia (115). However, controlled clinical studies are still lacking. Ketamine, an anesthetic for parenteral use, is effective in relieving pain in patients with chronic neuropathic disorders $(116,117)$ and those with fibromyalgia (70). However, systematic clinical studies have not been reported, probably due to unacceptable side effects. Investigations on other NMDA receptor antagonists are in progress $(118,119)$. Interestingly, many of the effects of NMDA receptor antagonists are mediated by the production of nitric oxide in the dorsal horn $(120,121)$. A Danish research group demonstrated that administration of nitric oxide synthetase inhibitors to patients with chronic pain significantly reduced muscle tenderness (122) and pain intensity (123).

The biopsychosocial perspective is still important The finding of neurobiologically explicable persistent pain in many musculoskeletal disorders does not support the future use of mainly pharmacological or other one-sided biological treatment measures. The concept of dysfunctional pain still focuses on the need for biopsychosocial 
treatment and rehabilitation models. Biological, social and cognitive perspectives should be included in the diagnostic process and in treatment.

However, there is much evidence to indicate that psychological factors are consequences of unrelieved pain rather than vice versa. Nevertheless, emotions and coping play a substantial role in the development and maintenance of chronic musculoskeletal pain. Emotional factors may influence dysfunctional synaptic connections (123) and cause changes in thalamic and cortical blood flow, thus modifying the perception of pain (124). Thus, secondary fear and depression may enhance a neurosomatic core of pain. Recent investigation also supports the notion that emotional distress due to long-standing pain may facilitate the development of dysfunctional central pain processing $(22,124)$.
Biological interaction between body and mind

There is substantial evidence that cognitive-behavioural therapy (essentially cognitive pain education) applied by interdisciplinary rehabilitation teams may reduce pain in fibromyalgia (125-129). Psychosocial support and cognitive restructuring (acknowledgment of the experience of pain, explanation of pain mechanisms including dysfunctional pain, other pain education, relaxation techniques, etc) often lead to constructive coping and reduce suffering. Results obtained from recent neuropsychological research support the hypothesis that cognitive therapy biologically influences central pain dysmodulation $(22,23)$, for instance, by reactivation of the centrally descending inhibition. Thus, it appears to be possible to modulate the plasticity of the central nervous system and partially repair dysfunctional pain mechanisms that were previously assumed to be irreversible.

\section{APPENDIX 1}

Terms associated with dysfunctional central pain modulation

\begin{tabular}{|c|c|}
\hline Sensitization & Increased pain caused by neurogenic hyperexcitability \\
\hline Peripheral sensitization & $\begin{array}{l}\text { Increased pain caused by hyperexcitability of peripheral nociceptors. May be caused by trauma, } \\
\text { inflammation, etc (primary hyperalgesia) }\end{array}$ \\
\hline Windup & Early and reversible hyperexcitability of the dorsal horn \\
\hline Central sensitization & $\begin{array}{l}\text { Increased pain caused by hyperexcitability of the dorsal horn and/or other parts of the } \\
\text { central nervous system (assumed to contribute to secondary hyperalgesia) }\end{array}$ \\
\hline Dysfunctional inhibition & $\begin{array}{l}\text { Dysfunctional central pain inhibition. Malfunctioning of descending noxious inhibitory } \\
\text { control or other central inhibitory mechanisms }\end{array}$ \\
\hline Dysfunctional central pain modulation & $\begin{array}{l}\text { Dysfunctional modulation of pain caused by central sensitization and/or dysfunctional } \\
\text { inhibition (in the present review designated as dysfunctional pain) }\end{array}$ \\
\hline Central plasticity & $\begin{array}{l}\text { Neuroanatomical restructuring of the central nervous system by synaptic growth, and/or } \\
\text { development of dendrites or other structural changes following long-standing noxious } \\
\text { stimulation. (Some research groups also include neurochemical dysfunction in this designation }\end{array}$ \\
\hline Allodynia & Pain due to a stimulus that does not normally provoke pain \\
\hline Hyperalgesia & Increased pain due to a normally painful stimulus \\
\hline Referred pain & $\begin{array}{l}\text { Pain referred to a distant region from a trigger point. Easily evoked, radiating diffuse pain } \\
\text { and/or peripheral dysesthesia (unpleasant abnormal sensations) without segmental or } \\
\text { otherwise neuroanatomical distribution. May be caused by activation of latent synaptic } \\
\text { connections in the dorsal horn (Figure 2). Compare with projected pain (due to rhizopathy } \\
\text { or nerve entrapment), which is segmentally distributed }\end{array}$ \\
\hline Delayed pain & $\begin{array}{l}\text { Development of easily evoked and increasing pain minutes or hours after non-noxious } \\
\text { muscle stimulation, such as palpation of trigger points or tender points and/or minor physical } \\
\text { exercise. May persist for hours or days (due to abnormal temporal summation [31]) }\end{array}$ \\
\hline
\end{tabular}

Allodynia, hyperalgesia and referred pain are defined according to the International Association for the Study of Pain Classification of Chronic Pain (55). Delayed pain, as defined above, has also been designated 'prolonged after-sensation' (31). Allodynia, hyperalgesia, referred pain and delayed pain are common clinical findings in chronic musculoskeletal pain disorders 


\section{REFERENCES}

1 Doubell TP, Mannion RJ, Woolf CJ. The dorsal horn: state-dependent sensory processing, plasticity and the generation of pain. In: Wall PD, Melzack R, eds. Textbook of Pain, 4th edn. Edinburgh: Churchill Livingstone, 1999:165-81.

2. Raja SN, Meyer RA, Ringkemp M, Campell JN. Peripheral neuronal mechanisms of nociception. In: Wall PD, Melzack R, eds. Textbook of Pain, 4th edn. Edinburgh: Churchill Livingstone, 1999:11-58.

3. Boivie J, Hansson P, Lindblom U, eds. Touch, Temperature, and Pain in Health and Disease. Mechanism and Assessments. Progress in Pain Research and Management, vol 3. Seattle: IASP Press, 1994.

4. Jensen TS. Mechanisms of neuropathic pain. In: Pain 1996 - An Updated Review. Refresher Course Syllabus. Seattle: IASP Press, 1996:77-86.

5. Eide PK. Wind-up and the NMDA receptor complex from a clinical perspective. Eur J Pain 2000;4:5-17.

6. Fields LH, Rowbotham MC. Multiple mechanisms of neuropathic pain: a clinical perspective. In: Gebhart GF, Hammond DL, Jensen TS, eds. Proceedings of the 7th World Congress on Pain. Progress in Pain Research and Management. Seattle: IASP Press, $1994: 437-54$

7. Hansson P, Kinnman E. Unmasking mechanisms of peripheral neuropathic pain in a clinical perspective. Pain Rev 1996:3:272-92

8. Dickenson AH. Pharmacology of pain transmission and control. In: IASP Comittee on Refresher Courses. Pain 1996 An Updated Review. Refresher Course Syllabus. Seattle: IASP Press, 1996:113-21

9. Cohen ML, Anogo JF, Champion GD, Browne CD. In search of the pathogenesis of refractory cervicobrachial pain syndrome. Med J Aust 1992;156:432-6

10. Ursin H, Endresen IM, Håland EM, Mjellem N. Sensitization: a neurobiological theory for muscle pain. In: Vaerøy H, Merskey H, eds. Progress in Fibromyalgia and Myofascial Pain. Amsterdam: Elsevier, 1993:413-27.

11. Henriksson KG. Muscle activity and chronic muscle pain. J Musculoskel Pain 1999;7:101-9.

12. Kramis RC, Roberts WJ, Gillette RG. Non-nociceptive aspects of persistent musculoskeletal pain. J Orthop Sports Phys Ther 1996;24:255-67.

13. Mense S. Neurobiologische Grundlagen von Muskelschmerz. Schmerz 1999;13:3-17.

14. Svensson P. Pain mechanism in myogenous temporomandibular disorders. Pain Forum 1997;6:158-65.

15. Sjölund B. Chronic pain in society - a case for chronic pain as a dysfunctional state? Qual Life Res 1994;3(Suppl 1):S5-9.

16. Woolf CJ. Wind-up and central sensitization are not equivalent. Pain 1996;66:105-8.

17. Li J, Simone DA, Larson AA. Windup leads to characteristics of central sensitization. Pain 1999:79:75-82.

18. Graven-Nielsen T, Aspegren Kendall S, Henriksson KG, et al. Ketamin reduces muscle pain, temporal summation, and referred pain in fibromyalgia patients. Pain 2000;85:483-91.

19. Kosek E, Ordeberg G. Abnormalities of somatosensory perception in patients with painful osteoarthritis normalize following successful treatment. Eur J Pain 2000;4:229-38.

20. Ma QP, Woolf CJ. Progressive tactile hypersensitivity: an inflammation-induced incremental increase in the exitability of the spinal cord. Pain 1996;67:97-106.

21. Woolf CJ, Salter MW. Neuronal plasticity: increasing the gain in pain. Science 2000;288:1765-8.

22. Flor $\mathrm{H}$, Birbaumer N. Basic issues in the psychobiology of pain. In: Gebhart GF, Hammond DL, Jensen TS, eds. Proceedings of the 7th World Congress on Pain. Progress in Pain Research and Management. Seattle: IASP Press, 1994:113-25.

23. Flor H, Braun C, Elbert T, Birbaumer N. Extensive reorganization of primary somatosensory cortex in chronic back pain patients. Neurosci Lett 1997;224:5-8.

24. Yunus MB. Towards a model of pathophysiology of fibromyalgia: aberrant central pain mechanisms with periphral modulation. J Rheumatol 1992;19:846-50.

25. Cohen ML, Quinter JL. Fibromyalgia syndrome: a problem of tautology. Lancet 1993;342:906-9.

26. Russell IJ. Neuroclinical pathogenesis of fibromyalgia syndrome. J Musculoskeletal Pain 1996;4:61-92

27. Arendt-Nielsen L, Graven-Nielsen, T Drewes AM. Referred pain and hyperalgesia related to muscle and visceral pain. IASP Newsletter January-February. Seattle: IASP Press, 1998:3-6.

28. Lindblom U. Differential diagnosis of muscular and neuropathic pain supported by quantitative sensory testing. In: Final Programme and
Abstracts of Plenary Sessions. 4th World Congress on Myofascial pain and Fibromyalgia. Silvi Marina: G.D'Annunzio University, 1998:59.

29. Leffler A-S, Kosek E, Hansson P. Injection of hypertonic saline into musculus infraspinatus resulted in referred pain and sensory disturbances in the ipsilateral upper arm. Eur J Pain 2000;4:73-82.

30. Waddell G, McCulloch A, Kummel E, Venner RM. Nonorganic physical signs in low back pain. Spine 1980;5:117-25.

31. Staud R, Vierck CJ, Cannon RL, Mauderli AP, Price DD. Abnorma sensitization and temporal summation of second pain (wind-up) in patients with fibromyalgia syndrome. Pain 2001;91:165-75.

32. Wiesenfeld-Hallin Z, Hao J-X, Xu X-J, Aldskogius H, Seiger A. Genetic factors influence the development of mechanical hypersensitivity, motor deficits and morphological damage after transient cord ischemia in the rat. Pain 1993;55:235-41.

33. Hartrick CT. Pain due to trauma including sports injuries. Pain Digest 1998;8:237-59.

34. Fitzgerald M. Developmental neurobiology of pain. In: Wall PD Melzack R, eds. Textbook of Pain, 4th edn. Edinburgh: Churchill Livingstone, 1999:235-51.

35. Lidbeck J, Hautkamp G, Ceder R, Näslund U. Classification of chronic pain at a multidisciplinary pain rehabilitation clinic. Pain Res Manage 1998;3:13-22.

36. Woolf CJ, Thompson SWN. The induction and maintenance of central sensitization is dependent on $N$-methyl-D-aspartic and receptor activation; implications for the treatment of post-injury pain hypersensitivity states. Pain 1991;44:293-9.

37. Pachard RC, Ham LP. Posttraumatic headache. J Neuropsychiatry 1994:6:229-36.

38. Schrieber S, Galai-Gat T. Uncontrolled pain following physical injury as the core-trauma in post-traumatic stress disorder. Pain 1993;54:107-10.

39. Livengood JM, Parris WCV. Post-traumatic stress disorder in chronic pain patients. Pain Digest 1996;6:290-4

40. Hagström Y, Carlsson J. Prolonged functional impairments after whiplash injury. Scand J Rehabil Med 1996;28:139-46.

41. Barnsley L, Lord S, Bogduk N. Whiplash injury. Pain 1994;58:283-307.

42. Barnsley L, Lord SM, Wallis BJ, Bogduk N. The prevalence of chronic cervical zygapophysial joint pain after whiplash. Spine 1995;20:20-6.

43. Koelbaek Johansen M, Graven-Nielsen T, Schou Olesen A, Arendt-Nielsen L. Generalised muscular hyperalgesia in chronic whiplash syndrome. Pain 1999;83:229-34

44. Moog M, Zusman M, Quinter J, Hall T. Allodynia and psychological profile in chronic whiplash patients. In: Abstracts. 9th World Congress on Pain. Seattle: IASP Press, 1999:409. (Abst)

45. Curatolo M, Radanow BP, Petersen-Felix S, Arendt-Nielsen L, Giani C, Zbinden AM. Is pain following whiplash injury associated with central nervous system hypersensitivity? In: Abstracts. 9th World Congress of Pain. Seattle: IASP Press, 1999:399. (Abst)

46. Fricton JR. Myofascial pain and whiplash. Spine 1993;7:403-22

47. Evans RW. Some observation on whiplash injuries. Neurol Clin 1993; 10:975-7

48. Hong CZ, Simons DG. Response to treatment for pectoralis minor myofascial pain syndrome after whiplash. J Musculoskeletal Pain $1993 ; 1: 89-131$

49. Buskila D, Neumann L, Vaisberg G, Alkalay D, Wolfe F. Increased rates of fibromyalgia following cervical spine injury. A controlled study of 161 cases of traumatic injury. Arthritis Rheum 1997;40:446-52

50. Buskila D, Neumann L. Musculoskeletal injury as a trigger for fibromyalgia/posttraumatic fibromyalgia. Curr Rheumatol Rep 2000;2:104-8

51. Foreman SM, Croft AC. Whiplash Injuries. The Cervical Acceleration/Deceleration Syndrome, 2nd edn. Baltimore: Williams and Wilkins, 1995

52. Sheater-Reid RB, Cohen ML. Regional cervicobrachial pain: correlation of psychophysical findings and clinical features. In: Abstracts. 8th World Congress on Pain. Seattle: IASP Press, 1996:278-9. (Abst)

53. Munglani R. Neurobiological mechanisms underlying chronic whiplash associated pain: the peripheral maintenance of central sensitization. J Musculoskeletal Pain 2000;8:169-78.

54. Simons D. Clinical and etiological update of myofascial pain from trigger points. J Musculoskeletal Pain 1996;4:93-121.

55. Merskey H, Bogduk N, eds. Classification of Chronic Pain. Descriptions of Chronic Pain Syndromes and Definitions of Pain Terms, 2nd edn. Seattle: IASP Press, 1994.

56. Wall PD, Woolf CJ. Muscle but not cutaneous C-afferent input produces prolonged increases in the excitability of the flexon reflex in the rat. J Physiol 1984;356:289-95. 
57. Dubner R. Hyperalgesia in response to injury to cutaneous and deep tissues. In: Fricton JR, Dubner R, eds. Orofacial Pain and Temporomandibular Disorders. New York: Raven Press, 1995:61-71.

58. Beylich G, Hoheisel U, Koch K, Mense S. Changes in the functional organization of the dorsal horn during acute myositis and following muscle nerve axotomy. In: Gebhart GF, Hammond DL, Jensen TS, eds. Proceedings of the 7th World Congress on Pain. Progress in Pain Research and Management. Seattle: IASP Press, 1994:251-64.

59. Mense S, Hoheisel U, Reinert A. Biochemical pathogenesis of myofascial pain. J Musculoskeletal Pain 1995;3(Suppl 1):16.

60. Coderre TJ, Katz J, Vaccarino AL, Melzack R. Contribution of central neuroplasticity to pathological pain: review of clinical and experimental evidence. Pain 1993;52:259-85.

61. Sheater-Reid RB, Cohen ML. Psychophysical evidence for a neuropathic component of chronic neck pain. Pain 1998;75:341-7.

62. Cohen ML. Arthralgia and myalgia. In: IASP Comittee on Refresher Courses. Pain 1996 - An Updated Review. Refresher Course Syllabus. Seattle: IASP Press, 1996:327-37.

63. Bendtsen L, Jensen R, Olesen J. Quantitatively altered nociception in chronic myofascial pain. Pain 1996;65:259-64.

64. Littlejohn GO. Clinical update on other pain syndromes. J Musculoskeletal Pain 1996;4:163-79.

65. Jensen R. Mechanisms of spontaneous tension-type headaches: an analysis of tenderness, pain threshold and EMG. Pain 1995;64:251-6.

66. Fillingim RB, Fillingim LA, Hollins M, Sigurdsson A, Maixner W. Generalized vibrotactile allodynia in a patient with temporomandibular disorder. Pain 1999;78:75-8

67. Sessle BJ, Hu JW, Cairns B. Brainstem mechanisms underlying temporomandibular joint and masticatory muscle pain. J Musculoskeletal Pain 1999;7:161-9.

68. Kuorinka I, Forcier L, eds. Work Related Musculoskeletal Disorders (WMSDs): A Reference Book for Prevention. London: Taylor and Francis, 1995.

69. Haldeman S. Low back pain: current physiologic concepts. Neurol Clin 1999;17:1-14.

70. Sörensen J. Pain Analysis. A Study in Patients with Chronic Low Back Pain or Fibromyalgia (dissertation). Linköping University Medical Dissertations No. 518. Linköping: Department of Medicine and Care, Division of Anaesthesiology, Faculty of Health Sciences, 1997.

71. Watson PJ, Booker CK, Main CJ. Evidence for the role of psychological factors in abnormal paraspinal activity in patients with chronic low back pain. J Musculoskeletal Pain 1997;5:41-56.

72. Clauw DJ, Williams D, Lauerman W, et al. Pain sensitivity as a correlate of clinical status in individuals with chronic low back pain. Spine 1999;24:2035-41.

73. Sidhall PJ, Cousins MJ. Spine update. Spinal pain mechanisms. Spine 1997;22:98-104.

74. Olmarker K, Brisby H, Yabuki S, Nordborg C, Rydevik B. The effects of normal, frozen, and hyaluronidase-digested nucleus pulposus on nerve root structure and function. Spine 1997;22:471-5.

75. Harrington JF, Messier AA, Beriter D, Barnes B, Epstein MH. Herniated lumbar disc material as a source of free glutamate available to affect pain signals through the dorsal root ganglion. Spine 2000;25:929-36.

76. Graven-Nielsen T, Sörensen J, Henriksson KG, Bengtsson M, Arendt-Nielsen L. Central hyper-excitability in fibromyalgia. J Musculoskeletal Pain 1999;7:261-71.

77. Dessein PH, Shipton EA, Stanwix AE, Joffe BI. Neuroendocrine deficiency-mediated development and persistence of pain in fibromyalgia: a promising paradigm? Pain 2000;86:213-5.

78. Kosek E, Hansson P. Modulatory influence on somatosensory perception from vibration and heterotopic noxious stimulation (HNCS) in fibromyalgia patients and healthy subjects. Pain 1997;70:41-51.

79. Lautenbacher S, Rollman GB. Possible deficiencies of pain modulation in fibromyalgia. Clin J Pain 1997;13:189-96.

80. Bendtsen E, Nørregaard J, Jensen R, Olesen J. Evidence of qualitatively altered nociception in patients with fibromyalgia. Arthritis Rheum 1997; 40:98-102.

81. Kosek E, Ekholm J, Hansson P. Sensory dysfunction in fibromyalgia patients with implications for pathogenic mechanisms. Pain 1996;68:375-83.

82. Værøy H, Helle R, Førre $\varnothing$, Kåss E, Terenius L. Elevated CSF levels of substance $\mathrm{P}$ and high incidence of Raynauds phenomenon in patients with fibromyalgia: new features for diagnosis. Pain 1988;32:21-6.

83. Værøy H, Nyberg F. Endogenous opioid peptides, substance P, calcitonin gene-related peptide and their relation to fibromyalgia. In: Værøy H, Merskey H, eds. Progress in Fibromyalgia and Myofascial Pain. Amsterdam: Elsevier, 1993:75-91.
84. Lord S, Barnsley L, Wallis B, Bogduk N. Chronic cervical zygapophysial joint pain after whiplash. A placebo-controlled prevalence study. Spine 1996;21:1737-45.

85. Lautenbacher S, Rollman GB, McCain GA. Multi-method assessment of experimental and clinical pain in patients with fibromyalgia. Pain 1994;59:45-53.

86. Merskey H. Pain and psychological medicine. In: Wall PD, Melzach RA, eds. Textbook of Pain, 4th edn. Edinburgh: Churchill Livingstone, 1999:929-49.

87. Williams DA, Keefe FJ. Pain beliefs and the use of cognitivebehavioural coping strategies. Pain 1991;46:185-90.

88. Hansen FR, Bendix T, Skov P, et al. Intensive, dynamic back-muscle exercises, conventional physiotherapy, or placebo-controlled treatment of low-back pain. Spine 1993;18:98-107.

89. Carosella AM, Lackner JM, Feuerstein M. Factors associated with early discharge from a multi-disciplinary work rehabilitation program for chronic low back pain. Pain 1994;57:69-76.

90. Oland G, Tveiten G. A trial of modern rehabilitation of chronic low back pain and disability. Vocational outcome and effect of pain modulation. Spine 1991;16:457-9.

91. Mellin G, Härkäpää K, Vanharanta H, Hupli M, Heinonen R, Järvikoski A. Outcome of a multimodal treatment inducing intensive physical training of patients with chronic low back pain. Spine 1993; 18:825-9.

92. Alaranta $\mathrm{H}$, Rytökoski $\mathrm{U}$, Rissanen $\mathrm{H}$, et al. Intensive physical and psychosocial training program for patients with chronic low back pain. Spine 1994;19:1339-49.

93. Swedish National Board Of Health and Welfare. Treatment of Chronic Pain. SoS-report. Stockholm: Socialstyrelsen, 1994:4.

94. Gamsa A. The role of psychological factors in chronic pain. I. A half century of study. Pain 1994;57:5-15.

95. Gamsa A, The role of psychological factors in chronic pain. II. A critical appraisal. Pain 1994;57:17-29.

96. Main CJ, Waddell G. Spine update. Behavioral responses to examination. A reappraisal of the interpretation of 'nonorganic signs'. Spine 1998;23:2367-71.

97. Fordyce WE, ed. Back Pain in the Workplace. Task Force on Pain in the Workplace. Seattle: IASP Press, 1995.

98. Teasell RW, Pain as a four letter word. Pain Res Manage 1996;1:63-4.

99. Merskey H. Back pain, psychology and money. Pain Res Manage 1996;1:13.

100. Thompson EN. Back pain: Bankrupt expertise and new directions. Pain Res Manage 1997;2:195-6.

101. Teasell RW, Merskey H. Chronic pain disability in the workplace. Pain Res Manage 1997;2:197-205.

102. Staats PS. Neuromodulation: advancing the pain paradigm for the next millenium. Pain Digest 2000;10:2-5.

103. Teasell RW. The denial of chronic pain. Pain Res Manage 1997;2:89-91.

104. Wall PD. The Science of Suffering. London: Weindenfeld Nicolson, 1999.

105. Arnér S. Pain analysis in prediction of treatment outcome. Acta Anaesth Scand Suppl 1998;113:24-8.

106. Meyerson BA. Pharmacological tests in pain analysis and in prediction of treatment outcome. Pain 1997;72:1-3.

107. Woolf CJ, Bennet GJ, Doherty M, et al. Towards a mechanism-based classification of pain? Pain 1998;77:227-9.

108. Woolf CJ, Decosterd I. Implications of recent advances in the understanding of pain pathophysiology for the assessment of pain in patients. Pain 1999;82(Suppl 6):S141-7.

109. Arnér S, Meyerson BA. Lack of analgesic effect of opioids on neuropathic and idiopathic forms of pain. Pain 1988;33:11-23

110. World Health Organization. Cancer Pain Relief: With a Guide to Opioid Availability. Geneva: WHO, 1996.

111. McQuay HJ, Moore RA. Antidepressants in neuropathic pain. In: An Evidence-Based Resource for Pain Relief. Oxford: Oxford University Press, 1998:231-41.

112. McCain GA. The clinical features of the fibromyalgia syndrome. In: Vaerøy H, Merskey H, eds. Progress in Fibromyalgia and Myofascial Pain. Amsterdam: Elsevier, 1993:195-215.

113. Watanabe Y, Saito H, Abe K. Tricyclic antidepressants block NMDAreceptor mediated synaptic responses and induction of long-term potentiation in rat hippocampal slices. Neuropharmacology 1993;32:479-86

114. Price DD, Mao J, Frank H, Mayer DJ. The N-methyl-D-aspartate receptor antagonist dextrometorphan selectively reduces temporal summation of second pain in man. Pain 1994;59:165-74.

115. Ilkjaer S, Driks J, Brennum J, Wernberg M, Dahl JB. Effect of systemic $\mathrm{N}$-methyl-D-aspartate receptor antagonist (dextromethorphan) on primary and secondary hyperalgesia in humans. Br J Anaesth 1997;79:600-5. 
116. Mathisen LC, Skjelbred P, Skoglund LA, Oye I. Effect of ketamin, an NMDA receptor inhibitor, in acute and chronic orofacial pain. Pain 1995;61:215-20.

117. Felsby S, Nielsen J, Arendt-Nielsen L, Jensen TS. Effect of NMDA receptor antagonism with ketamin and magnesium chloride in chronic neuropathic pain. Pain 1996;64:283-91.

118. Dickenson A. Novel pharmacological targets in the treatment of pain. Pain Rev 1995;2:1-12

119. Sakiennik AW, Krearn RM. N-methyl-D-aspartate receptors in pain. Curr Opin Anaesthesiol 1995;8:445-9.

120. Mizukawa K, Vincent SR, McGeer RL. Distribution of reduced nicotinamide-adenine-dinucleotide-phosphate diaphorasepositive cells and fibres in the cat central nervous system. J Comp Neurol 1989;279:281-311.

121. Morris R, Southam E, Gittins SR, de Vente J, Garthwaite J. The NO-cGMP pathway in neonatal rat dorsal horn. Eur J Neurosci 1994;1:876-9.

122. Ashima M, Bendtsen L, Jensen R, Lassen LH, Sokai F, Olesen J. Possible mechanism of action of nitric oxide inhibitors in chronic myofascial pain. J Musculoskeletal Pain 1998;6(Suppl 2):56.
123. Ashima M, Lassen LH, Bendtsen L, Jensen R, Olesen J. Effect of inhibition of nitric oxide synthase on chronic tension-type headache: a randomised crossover trial. Lancet 1999;353:287-9.

124. Ursin H. Sensitization, somatisation, and subjective health complaints. Int J Behav Med 1997;4:105-16.

125. Bennett R. Chronic widespread pain and the fibromyalgia construct. Pain Digest 1999;9:292-8.

126. Nielson WR, Harth M, Bell DA. Out-patient cognitive-behavioural treatment of fibromyalgia: Impact on pain response and health status. Pain Res Manage 1997;2:145-50.

127. Bennett RM, Burckhardt CS, Clark SR, O'Reilly CA, Campell SM. Group treatment of fibromyalgia: a 6 month outpatient program. J Rheumatol 1996:23;521-8.

128. Krøll F, Bruvik M, Pallisgaard EM, Arntsen R, Wigers SH. Outcome from the Skogli fibromyalgia treatment program. J Musculoskeletal Pain 1998;6(Suppl 2):129.

129. Turk D, Okifuji A, Sinclair JD, Starz TW. Interdisciplinary treatment for fibromyalgia syndrome: clinical and statistical significance. Athritis Care Res 1998;11:186-95. 


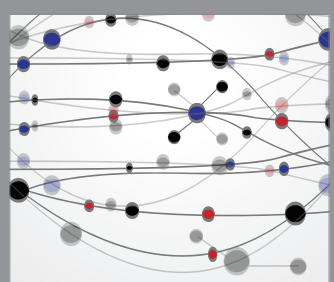

The Scientific World Journal
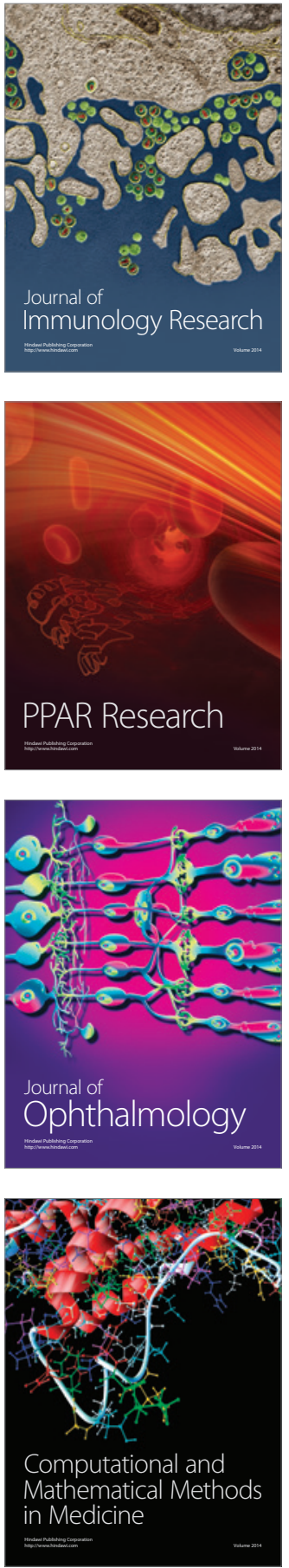

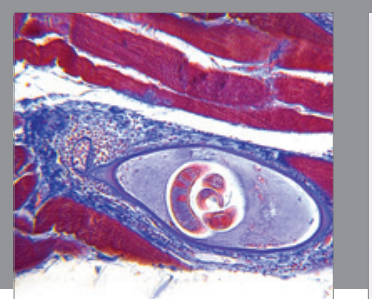

Gastroenterology Research and Practice

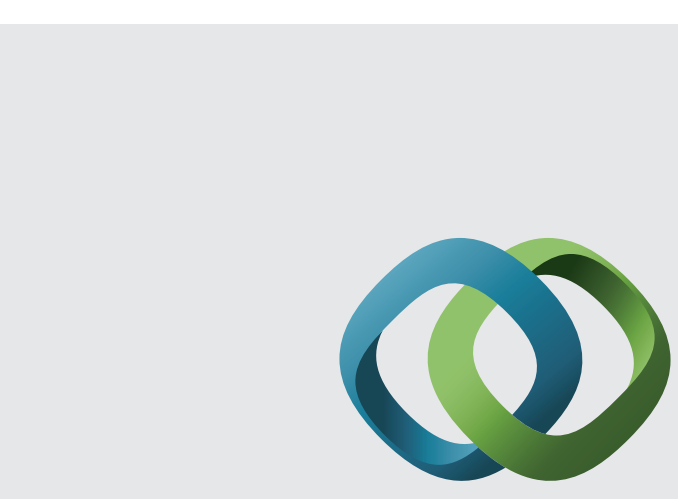

\section{Hindawi}

Submit your manuscripts at

http://www.hindawi.com
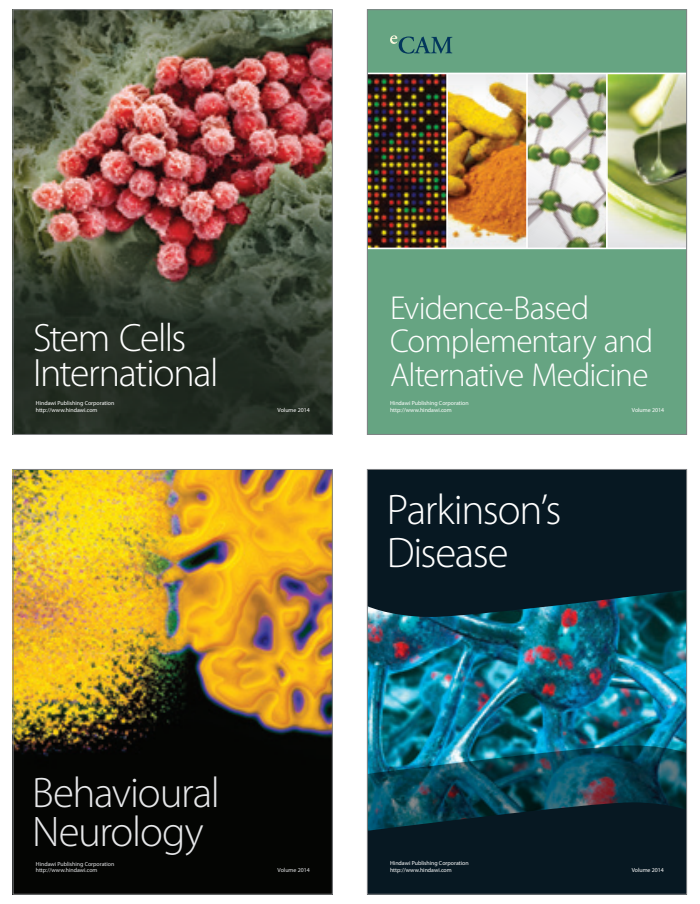
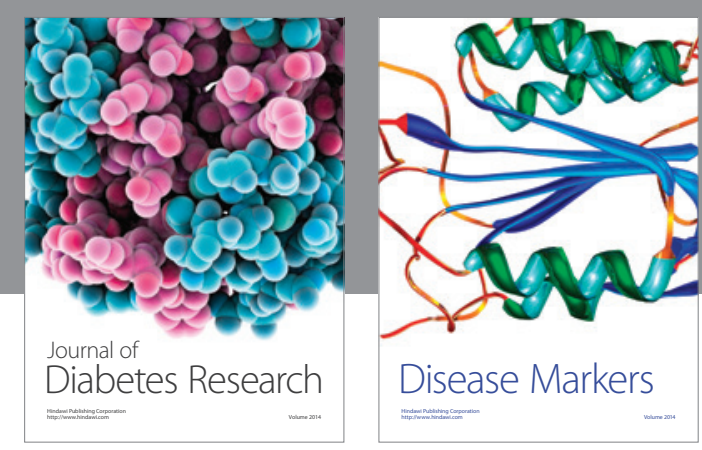

Disease Markers
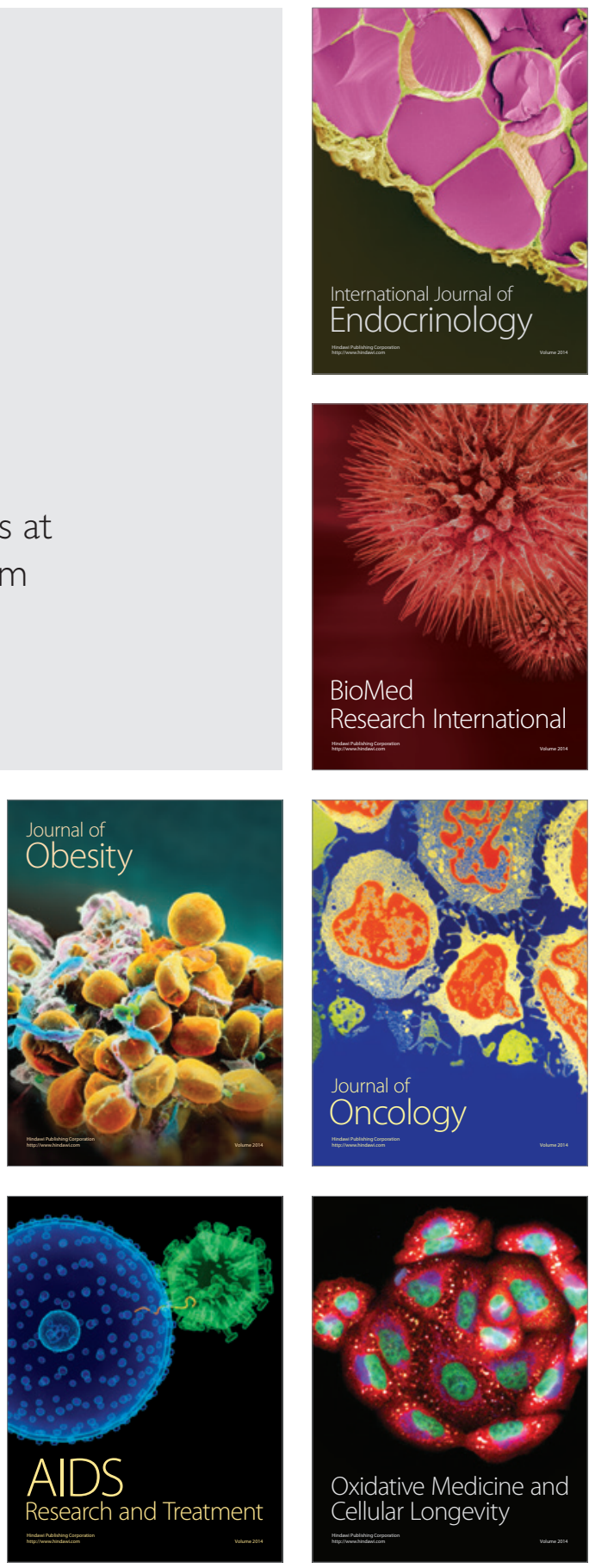